\title{
Gender, Domestic Violence, and Patterns of Conviction: Analysis of India's Supreme Court Rulings*
}

\author{
Preethi Krishnan \\ $\&$ \\ Mangala Subramaniam
}

Acknowledgments: We thank the anonymous reviewers and the editors for their insightful comments and suggestions.

* An earlier version of this paper has been accepted for presentation at the 2015 ASA annual meetings. 


\section{Abstract \\ Gender, Domestic Violence, and Patterns of Conviction: Analysis of India's Supreme Court Rulings}

Purpose- The practices and arrangements within a family can create grounds for violence. Although we agree that family processes are important, we think that these explanations downplay the structure of families (nuclear, extended) and thereby the ways in which gender relations are organized. In this paper, domestic violence is explored as an intra-family dynamic that extends beyond the intimate partner relationship and which seeps into court rulings of cases of such violence.

Design/methodology/approach- Using archival data from 164 Supreme Court case decisions on domestic violence in India for the period 1995-2011, we examine both the patterns of conviction and the complexities of gender relations within the family by systematically coding the Court's rulings.

Findings - Analysis of court rulings show that mothers-in-law were convicted in $14 \%$ cases and the husband was convicted in $41 \%$ cases. We call attention to the collective nature of the domestic violence crime in India where mothers-in-law were seldom convicted alone (3\% of cases) but were more likely to be convicted along with other members of the family. Two dominant themes we discuss are: the gendered nature of familial relations beyond the intimate partner relationship and the pervasiveness of such gendered relationships from the natal home to the marital family making victims of domestic violence isolated and 'homeless.'

Research limitations/implications - Future research may benefit from using data in addition to the judgments to consider caste and class differences in the rulings. An intersectionality perspective may add to the understanding of the interpretation of the laws by the courts.

Social implications - Insights from this paper have important policy implications. As discussed in the paper, the unintended support for violence from the natal family is an indication of their powerlessness and therefore further victimization through the law will not help. It is critical that natal families re-frame their powerlessness which is often derived from their status as families with daughters. Considering that most women in India turn to their natal families first for support when they face violence in their marriages, policy must enable such families to act and utilize the law.

Originality/Value - By examining court rulings on cases of domestic violence in India we focus on the power exerted by some women particularly within extended families which is central to understanding gender relations within institutions. These relations are legitimized by the courts in the ways they interpret the law and rule on cases.

Keywords: gender, family, domestic violence, court judgments, India 
Violence against women takes diverse forms across the world. Yet, most women experience violence not from strangers but from known persons. ${ }^{1}$ A multi-country study by the World Health Organization estimates the lifetime prevalence of domestic violence against women to vary from $15 \%$ to $71 \%$ in 15 sites across 10 countries including the US and India (Garcia-Moreno et al. 2005). Intimate partner violence (IPV), and in particular wife abuse by husbands, is a human rights and public health concern throughout the world.

Intimate partner violence (IPV) includes physical violence, sexual violence, stalking and psychological aggression (including coercive tactics) by a current or former intimate partner (Breiding et al., in press). An intimate partner is a person with whom one has a close personal relationship that may be characterized by the partners' emotional connectedness, regular contact, ongoing physical contact and sexual behavior, identity as a couple, and familiarity and knowledge about each other's lives; however, the relationship need not involve all of these dimensions (Breiding et al., in press). In the western context, domestic violence is often seen as intimate partner violence with little consideration of the structure of the family (nuclear versus extended).

Domestic violence in South Asia has received special attention because of both its prevalence and severity. More than $60 \%$ of Indian women reported three or more episodes of physical or psychological violence in their lifetime (Ahuja et.al. 2000). Indian studies indicate that $33 \%$ to $40 \%$ of domestic violence cases include the wider household, including female relatives of the husband as perpetrators or instigators of violence (Panchanadeswaran and Koverola 2005; Dave and Solanki 2000). Even where it does not culminate in death, many young Indian married women often suffer violence at the hands of their mothers-in-law. Some evidence

\footnotetext{
${ }^{1} \mathrm{http}: / /$ www.un.org/en/women/endviolence/pdf/pressmaterials/unite_the_situation_en.pdf
} 
exists of mothers-in-law being arrested and convicted in cases of dowry-related deaths (Cherukuri et.al 2009). Other family members of the husband too are involved in perpetrating violence. In fact, the husband and his relatives are included in India's laws as potential perpetrators of domestic violence. In 2011, more than $40 \%$ of crimes against women in India were accounted under "cruelty by husband and relatives" (National Crime Records Bureau 2011). It includes women being convicted for inflicting violence on other women within the extended family. Such violence has implications for gender theory and for the interpretation of the law by the court in case rulings.

First, our analysis has implications for gender theory. We note that intra-family dynamics involves not only men exerting power; it also includes women wielding some degree of control particularly in extended (or joint) families. Men and women are often held accountable to stereotypes that define their sex category and who engage in gendered practices for social approval (Martin 2003; West and Zimmerman 1986). In some cultural contexts, such as India, some women are afforded formal and informal power within the family. Therefore, analyzing the involvement of women in exerting power adds to insights about how gender permeates social institutions such as the extended family. We examine how practices and arrangements of family are associated with violence and have implications for who is charged by the court as well as how this seeps into court rulings particularly in convictions.

Second, many countries/territories worldwide, including India, have adopted laws, or revised existing legislation and amendments to their constitutions, to address violence against women more effectively (Ortiz-Barreda and Vives-Cases 2013; Krishnan and Subramaniam unpublished). Law-making in itself does not guarantee enforcement of the law. The court's interpretation of the law determines who is charged and convicted in cases of domestic violence. 
So the text of the court's judgments can provide insights into whether and how power exerted by some women in extended families is legitimized (or not). While much scholarly work on domestic violence in the Indian context focuses on the family and dowry including the law (cf. Agnes 2011; Ghosh and Choudhuri 2011; Cherukuri et al 2009; Subramaniam et al 2009; Visaria 2000; Agnes 1992), there has been no systematic analysis of the rulings of India's Supreme Court in terms of who (if any) is convicted in the cases and whether, and how, the underlying basis of the judgments is the gender relations in the family. ${ }^{2}$ We undertake such an analysis in this paper.

Using archival data from 164 Supreme Court decisions on domestic violence cases in India for the period 1995-2011, we examine both the patterns of charges and of conviction that is who from the family was implicated and convicted. We also analyze the complexities of gender relations within the family by systematically coding the textual data of court rulings. Our analysis show that India's Supreme Court has convicted women as perpetrators of the violence with the mother-in-law being implicated in $61 \%$ of the cases in contrast to the husband being implicated in more than $90 \%$ of the cases. The trends in conviction show that the court is not hesitant in implicating women who are typically viewed as passive and docile in the Indian cultural context. In addition to examining patters in conviction across members of the family, we discuss two dominant themes in the rulings: the gendered nature of familial relations beyond the intimate partner relationship and the pervasiveness of such gendered relationships from the natal home to the marital family making victims of domestic violence isolated and 'homeless.'

\section{Gender, Family, Violence, and Law}

\footnotetext{
${ }^{2}$ In India, the Supreme Court is the highest appellate court which considers appeals against judgments rendered by state level High Courts.
} 
Gender scholars have contributed extensively to examining and understanding domestic violence across countries (cf. Abraham 2004; Cherukuri et.al. 2009; Visaria 2000; Narayan 1997; Agnes 1992; Dobash and Dobash 1979). One of the biggest challenges to criminalizing domestic violence lies in the private nature of the crime itself. Violence in the private space of the family has been documented as a critical location for violence in the form of physical, mental and sexual abuse against women and children (Abraham 2004; Cherukuri et.al. 2009; Narayan 1997; Visaria 2000; Crenshaw 1991; Collins 1998; Dobash and Dobash 1979). Women's subordination has been legitimized through the family structure and is further reinforced by other social, political and economic institutions (Dobash and Dobash 1979). In this paper, we emphasize an analysis of the state's gender regime or the "state of play of gender relations in a given institution" (Connell 1987: 120) specifically the family.

Research on violence and family during the past decade has focused on the types of violence and its interconnections with larger structures of power and inequality (cf. Anderson 2010; Loseke 2003). Particularly, applying structural approaches and considering intersections of gender, race and class has extended understandings of the connections between power and family violence. In her review essay on feminism and family research, Ferree (1990) states that "feminists agree that male dominance within families is part of a wider system of male power, is neither natural nor inevitable, and occurs at women's cost" (p. 866).

Violence grows out of inequality within marriage and reinforces men's dominance and women's subordination within the home and outside of it. The conceptualization of violence as coercive control is important for considering it as a tactic of entitlement and power that is deeply gendered (Yllö 2003). The practices and arrangements within a family can create grounds for violence. Family processes such as marital relations including marital instability can lead to 
violence (Hoffman et al 1994). Although we agree that family processes are important, we think that these explanations downplay the structure of families - nuclear versus extended - and therefore the ways in which gender relations are organized. Our interest in this paper is to examine the role of extended family members in cases of domestic violence adjudicated by the court, a major state institution.

State institutions are central to the critical analyses work of gender scholars (cf. Brown 1995; Ferguson and Gupta 2002; Brush 2003; Sunder Rajan 2003). Among them are those who emphasize the positive role of women legislators, judges, and bureaucrats active inside the state referred to as 'femocracts' - who can change the governance of gender (Eisenstein 1996; Mazur 2001; Stetson 2001). This group includes feminists who find promise in India's laws that pertain to dowry and domestic violence (Kapur 2005; Menon 2004). They, however, point out that merely getting laws enacted will not alter the structural subordination of women who are viewed as passive and dependent. Yet in in the Indian context some women within the family exert power and so the court must recognize the structure of gender relations within families. The court cannot afford to just mechanically follow the rules laid down by the legislature; they must interpret the rules so as to reconcile them with the wider objectives of justice. Because gender relations within families, and particularly extended families, varies across cultures and contexts, we begin with a detailed discussion of family, dowry, and domestic violence in India.

\section{Family, Dowry, and Domestic Violence in India}

In the Indian context, the notion of the family is complex because it often includes the extended family members and is referred to as the 'joint' (or extended) family. ${ }^{3}$ Structural forces such as economic development, increased education and literacy, and advanced communication

\footnotetext{
${ }^{3}$ We use the terms 'joint' and 'extended' interchangeably.
} 
and information systems impact cultural values and in turn family structures and relationships. India is a part of such change but it is also a country of contrasts and complexities.

In India, arranged marriages are generally the norm. In fact, marriage is viewed as an alliance between two families rather than two individuals. While there have been some shifts in trends in marriage, Netting's (2010) study in a small city in India confirms the continuing role of the family in arranging marriages. Marriages based on familial introductions are seen as generally more stable because they guarantee similarity of religion and social class. Women generally marry into patrilineal, patrilocal families where authority is based on the relations among adult males rather than on the conjugal bonds between spouses (Madan 1993). Below we discuss the interrelatedness of two strands of literature that are important for our analysis of India's Supreme Court's rulings on cases of violence: intra-family dynamics and the state and law.

\section{Family, Domestic Violence, and the Law}

While there are large variations, intra-family dynamics in the Indian context are based on gender relations. A woman's place is, in large part, defined by her relationship to the family, where her power and involvement in decision making can vary based on her age and whether she has a son. Gender differences are also the basis of basic needs. Studies provide accounts of practices that differentially allocate resources such as, food and medical care based on gender. Within households, particularly poor households, there is a strong preference for supporting sons over daughters and men over women (Gupta 1987; Griffiths, Matthews, \& Hinde 2002; Messer 1997; Sen 1993).

Generally older women have more power than younger women, especially new brides, in the family. However, the birth of a son bestows considerable status on the woman (the mother). 
The family structure is a paradox in that it is constraining as well as supportive of women. Women are often viewed as liabilities in their natal families and are expected to 'adjust' in their marriages even in the face of harassment. Yet, because the family (particularly the extended family) is supportive in matters such as child care (Karlekar 1998), women seldom choose to break away from their families even when they face violence.

Social relations in the domestic sphere are further complicated by the fact that many women enter their husband's families at very young ages as a result of arranged marriages. A desire for very early marriages results in urgency among parents who are willing to pay any "price" (dowry) to "buy" a groom. Dowry refers to the payment of money, goods and property to the groom's family by the bride's family. Dowry, in its most basic form, has been interpreted as a form of pre-mortem inheritance for women who otherwise lack inheritance rights equal to those of men.

Over the decades, the dowry demands of the groom and his family have grown and continue through the period of marriage. Not meeting the demands leads to harassment, violence, and sometimes death. Dowry related harassment, sometimes resulting in so-called 'dowry death' or 'bride burning' (Leslie 1998; Butalia 2002) became an increasing burden facing women. The pervasiveness of dowry-related violence is evident in the increasing number of cases of dowrydeaths. According to the Indian government, there were 8,083 dowry deaths in 2013 (National Crime Records Bureau 2013). ${ }^{4}$

Prior to the 1980s, violence against women in India received limited attention from either women's organizations, political parties, or the media. While state initiated actions put issues involving women's economic welfare on the agenda, it was women's groups outside of the government that placed body politics on the agenda (Katzenstein 1989, 1991-92). The framing of

\footnotetext{
${ }^{4}$ http://ncrb.gov.in/CD-CII2013/figure\%20at\%20a\%20glance.pdf accessed on May 3, 2015
} 
dowry-related deaths as private and as an issue internal to a family were challenged by women's groups who showed that many official 'suicides' were 'murders.'

Some scholars call for thinking about whether it is the dowry system itself or more specifically the abuse linked to dowry that has to be rallied against (cf. Kishwar 1988). For Kishwar, the potential of dowry to provide women with some form of inheritance that could improve their position within their marital homes is to suggest that they make even greater martyrs of themselves than society makes of them (2005). Others such as Palriwala (1989) and Lakshmi (1989), reject Kishwar's position and argue that dowry itself is inherently problematic for women because it is primarily transacted between men and is premised on the inferiority of the bride's future contribution to her husband and his family who must therefore be financially compensated for.

Although there has been a tendency to focus on the violent aspects of dowry-giving and legal solutions (maybe rightly so), it is important to recognize the underlying structural gender inequalities in examining the practice of dowry. It is necessary to distinguish between cultural practices and patriarchal practices. Where cultural practices reflect and perpetuate gender discrimination, the law must be ever more cognizant of the underlying causes of violence against women.

We underscore two important points about domestic violence in India. The first is that domestic violence may be related to or unrelated to dowry demands and second, it need not always be perpetuated by men alone; the husband and his family may also be involved in the act of violence. Scholars provide a variety of understandings of domestic violence in India. While some conceptualize it as primarily violence by men against women (Kapur and Cossman, 1996; Mehra, 1998), others include mothers-in-law and others from the husband's family and explain it 
as a proxy of men's acts of violence (Fernandez 1997). These understandings are not incorporated in analyses of legislative debates in India (Gangoli and Rew 2011). Less is known about whether state institutions such as the courts implicate (or not) the mother-in-law or other extended family members and on what basis.

Feminist legal studies in India and elsewhere examine how law is embedded in patriarchal power. There are some who see no possibility of achieving justice through legal intervention (cf. Menon 1998). While feminist politics rarely makes a dent into the state agenda, feminist involvement with the law provides the state a possibility to enter realms which were closed to it, such as the family. Moreover, feminist intervention also legitimizes state power. Some scholars, such as Menon (2004), therefore call for discarding the legal arena as a fruitful realm for change. Others, such as the NGO, Lawyers Collective of India and the state institution, National Commission for Women differ in their opinion and have been actively collaborating to pressure the state (cf. Kandiyoti 1988; Fernandez 1997; Subramaniam et al 2014). The differing notions of working with the state in itself poses a challenge to gendered policy-making. Yet making of policy or a law is only one dimension to addressing violence; the interpretation of the law in court rulings is a critical piece that needs systematic scrutiny. An overview of domestic violence related laws in India will be useful for understanding the analysis.

\section{Domestic Violence Laws in India}

In this paper we analyze cases that refer to the four domestic violence laws: The Dowry Prohibition Act 1961, Section 498A, Section 304B and Protection of Women from Domestic Violence Act 2005. The first legislation to ban dowry (not the related domestic violence per se) is the Dowry Prohibition Act, 1961. This 1961 law defines dowry as "property or valuable security given or agreed to be given either directly or indirectly... at or before or any time after 
the marriage in connection with the marriage of the said parties." The Act explicitly covers both the giver and taker of dowry (parents or other relatives or guardian of a bride or bridegroom) as being punishable. This definition of dowry, as we discuss below, is key to adjudication of cases of dowry deaths. The 1961 law saw minor amendments in the 1980s.

The 1980s also saw two major additions to the Indian Penal Code (IPC): Section 498A and Section 304B. The Indian Penal Code, comprising more than 500 sections, is a comprehensive code that covers all substantive aspects of criminal law. Section 498A was inserted into the IPC through an amendment in 1983 to address dowry harassment, suicide, and included mental cruelty. This section made cruelty to the wife by husband or his relatives as a cognizable, non-bailable offense. Section 304B was inserted into the IPC through an amendment in 1986. It specifically deals with dowry deaths. Acknowledging the absence of circumstantial evidence in most cases of murders that happen within the privacy of the family, Section 304B deals with dowry deaths and transfers the burden of proof to the husband or his family.

In 2005, the Protection of Women from Domestic Violence (PWDVA) Act was enacted to fill the gaps of existing domestic violence laws in India particularly the three laws (noted above) which focused on dowry related violence. The PWDVA Act 2005 is the first of its kind to provide a comprehensive definition to domestic violence by including physical, emotional, sexual, verbal and economic abuse as violence. While the earlier three domestic violence laws were criminal laws, the PWDVA is a civil law aimed at protecting women from future violence. The PWDVA ensures that women have access to their marital home, claim to maintenance and right to custody over children, rather than merely punishing the husband (Suneetha and Nagaraj 2005). An innovative aspect of the PWDVA is the inclusion of a woman's "right to shared household." The husband and his relatives often have the wife leave the marital home and so in 
order to protect women from such situations, the law provides them the right to the marital home, even if the property may not be in her or her husband's name.

By analyzing the rulings of the highest court, Supreme Court, in India, we provide insights into how extended family members may be charged and convicted (or not) as perpetrators. As state institutions often legitimize gender inequality and tend to discourage any challenge to this order (cf. Dobash and Dobash 1979), we expect the Supreme Court of India to also resist challenges to the existing social order. Consequently, while adjudicating domestic violence cases, we expect that the Supreme Court will operate on gendered assumptions by prioritizing the family over women's rights. The court's rulings, we propose, will fail to consider notions of gender relations within Indian families and will therefore be less likely to convict women from the husband's family.

\section{Data and Methods}

The data for this paper are case decisions of India's Supreme Court for the period 1995 to 2011. During this period, a total of 164 cases refers to one or more of the four domestic violence laws in the Indian legal system - Dowry Prohibition Act 1961, Section 304B in the Indian Penal Code, Section 498A in the Indian Penal Code and Protection of Women from Domestic Violence Act 2005. Of the 164 cases, more than 35 cases referred to the Dowry Prohibition Act, 1961, about 90 cases referred to Section 498A, and about 50 cases utilized Section 304B. Only six of the 164 cases referred to the 2005 PWDVA. Most judgments use a combination of laws which include but are not limited to the four domestic violence laws.

The 164 case decisions comprising 2,025 pages are publicly available at http://judis.nic.in/supremecourt/chejudis.asp. Using the search engine available on this website, we searched for and downloaded cases that refer to the above mentioned laws for the period from 
1995 to 2011 . These data are part of a larger project examining judgments pertaining to domestic violence. We are therefore well acquainted with the data.

Each judgment typically contains: the year the decision was delivered, the name of the appellant, name/s of the respondent/s, the name of the panel of judge/s (one or two), and a record of the text of the decision. The text of the decision typically outlines the case background such as demands (as dowry) made, the incident of violence or death by fire or other means, and the sentence, if any. However, not all judgments contain all the information.

\section{Analytic Strategy}

Keeping in mind, the above referred key laws that address domestic violence, dowry related or not, we utilized qualitative methods to analyze the court decisions. We used a combination of directed content analysis and conventional content analysis (Berg 2009). "Directed content analysis involves the use of more analytic codes and categories derived from existing theories and explanations relevant to the research focus. In this case, the investigator will immerse himself or herself in the raw data, using these themes and those that may emerge from the data itself" (Berg 2009: 341). Conventional content analysis uses a grounded theory approach whereby codes are derived inductively from the data. Combining a deductive and inductive approach, we open-coded the text of the decisions using NVivo.

The analytic strategy was limited to the language of the decisions and value judgments about specific rulings were avoided. A gendered analysis requires the researcher to look for “disparate treatment" and "disparate impact" (England 1998). In this study, we examine the disparate treatment and impact of domestic violence laws and their interpretation (cf. Krishnan and Subramaniam unpublished). Disparate treatment suggests that the policies by themselves are discriminatory towards women but they become complicated in extended family settings as some 
women exert power over others, such as the mother-in-law over a daughter-in-law. We therefore examine the Supreme Court's rulings for patterns of conviction, if women were implicated, and for broader themes of family dynamics. Several cases included the mother-in-law or sister-in-law as a perpetrator (discussed below).

Combining a grounded theory approach for an initial set of themes with systematic coding, we looked for gendered practices engaged in by women which resulted in other women's subordination. In the first step, the court rulings were coded as (a) favorable, (b) unfavorable and (c) not applicable. A verdict was coded "favorable," when either the husband or relative was convicted of the crime or the husband or his relatives were denied bail or the woman was offered maintenance if that was her claim. There were cases for which rulings were partially favorable or partially unfavorable. For example, the woman would have died and the husband or his relative would have been convicted only for cruelty but acquitted for charges concerning her death. Such partial verdicts were coded "favorable" in order to be conservative in our analysis.

Cases in which the woman herself did not want to pursue the criminal case and requested for compromise were coded as "not applicable." Such compromises have often been allowed by the Supreme Court. Two cases in which the wife had filed a case against her husband's girlfriend were coded as "not applicable." In both these cases, the Court ruled that the girlfriend cannot be a relative and therefore cannot be charged under these laws. While this verdict is indeed against the wife, the defendant as a woman may be in a position similar to that of the wife. In contrast, cases in which the husband or a relative was acquitted of domestic violence charges were coded "unfavorable" even if they were charged under other sections such as polygamy.

In the second step, patterns in terms of who was implicated (charged) and who was convicted were coded. The third step entailed discerning key themes of family dynamics invoked 
in the court rulings. In this analysis, we are indirectly engaging with women who had faced violence by reading through narrations in case decisions written by judges. Although we are Indian by ethnicity, our upbringing was predominantly urban with access to education and job opportunities. So, while we are in a unique position to interpret cultural practices, we felt some instances of extreme violence as 'foreign.' While our familiarity with cultural norms does provide some insights into analyzing the narratives in these case decisions, our personal experiences with Indian families and state institutions, alongside the theoretical framework of gender provide a unique lens in this analysis.

\section{Analysis: Gender, Domestic Violence, and Court Rulings}

Our analysis of the 164 Supreme Court rulings comprises two parts. In the first part, we present patterns in outcomes for the victim of violence (the woman who is the wife) followed by the patterns in charges and convictions for domestic violence crimes. In the second part, we describe two main themes that emerged from the systematic qualitative analysis of the textual data. The first theme - relationships of power within the family - demonstrates the complexities of the Indian family structure and the hegemony of the gender structure beyond the intimate partner relationship. The second theme - homeless in their own homes - demonstrates how gender is embedded within families across the bride's natal home and her marital home. These analyses draw attention to variations in the structure of families across cultural contexts which in turn is important for understanding how gender permeates the social institution of the family affording some women power. This makes victims of domestic violence isolated and 'homeless'.

\section{Overview of Cases}

As discussed above, our analytic strategy involved the coding of the court verdict as favorable, unfavorable, or not applicable. Refer to table 1. For the period 1995-2011, about 58\% of the cases led to favorable verdicts, about $36 \%$ were unfavorable, and $6 \%$ were not applicable. 
The outcomes also varied depending on who was the petitioner, the family ties of the petitioner (of the wife's family or husband's family), who was the judge, and whether the woman (victim) of violence was alive or not. Refer to table 2 .

\section{Table 1}

\section{Outcome of Rulings}

\begin{tabular}{|l|l|}
\hline Outcomes & Favorable \\
\hline Favorable & $95(57.9 \%)$ \\
\hline Unfavorable & $59(36.1 \%)$ \\
\hline Not Applicable & $10(6.1 \%)$ \\
\hline Total & $164(100 \%)$ \\
\hline
\end{tabular}

In about $73 \%(\mathrm{~N}=164)$ of cases, the primary petitioners were men. About $20 \%$ of primary petitioners were women and about $7 \%$ of cases were taken forward by the state. There was only a small difference in the favorable outcome (as favorable to the woman) when the primary petitioner was a woman versus a man. While about $61 \%(\mathrm{n}=33)$ of outcomes were favorable to the wife when a woman was the petitioner, $56 \%(\mathrm{n}=119)$ of outcomes were favorable when a man was the petitioner. However, the petitioner whether man or woman could be from the wife's family or from the husband's family. Thus, the gender of the petitioner may not have a direct influence on the outcome of the case.

The primary petitioner was from the husband's family in a majority of the cases $(79 \%)$ and only $54 \%$ of these outcomes were favorable to women. In contrast, when the petitioner was from the wife's family the outcome was favorable to the wife and/or her family in $77 \%$ cases $(n=22)$. A distressing statistic as seen in table 2 is that the woman had died in the majority of cases $(68 \% ; \mathrm{N}=164)$ reaching the Supreme Court (when the case was filed). Her death could be 
a suicide or homicide. Thus, the language in many of the decisions were rather sympathetic towards the woman and included comments about dowry as a social evil. ${ }^{5}$

Table 2

Outcome by Petitioner and Victim Alive or not

\begin{tabular}{|l|r|r|l|l|}
\hline Outcomes & Favorable & Unfavorable & Not Applicable & Total \\
\hline Petitioner & & & & \\
Man & $67(56.3 \%)$ & $47(39.5 \%)$ & $5(4.2 \%)$ & $119(72.6 \%)$ \\
Woman & $20(60.6 \%)$ & $10(30.3 \%)$ & $3(9.1 \%)$ & $33(20.1 \%)$ \\
$\quad \begin{array}{l}\text { State } \\
\text { Total }\end{array}$ & $7(58.3 \%)$ & $4(33.3 \%)$ & $1(8.3 \%)$ & $12(7.3 \%)$ \\
\hline Petitioner's Ties & & & & $164(100 \%)$ \\
\hline $\begin{array}{l}\text { Husband's family } \\
\text { Wife's family }\end{array}$ & $70(53.8 \%)$ & $53(40.8 \%)$ & $7(5.4 \%)$ & $130(79 \%)$ \\
$\begin{array}{l}\text { State } \\
\text { Total }\end{array}$ & $7(58.3 \%)$ & $4(33.3 \%)$ & $1(8.3 \%)$ & $22(13 \%)$ \\
\hline Victim of violence & & & & $12(7 \%)$ \\
(when case filed) & & & & $164(100 \%)$ \\
$\quad \begin{array}{l}\text { Dead } \\
\text { Alive }\end{array}$ & $71(64.0 \%)$ & $37(33.3 \%)$ & $3(2.7 \%)$ & $111(68 \%)$ \\
Total & $23(43.4 \%)$ & $24(45.3 \%)$ & $6(11.3 \%)$ & $53(32 \%)$ \\
\hline
\end{tabular}

\section{Patterns of Conviction}

A total of 107 (65\%) families in these cases are extended (joint) families; 34 (21\%) are nuclear families, and the family form in the remaining $23(14 \%)$ is unclear. Patterns of conviction by the Supreme Court demonstrate the influence of the extended family on the occurrence of domestic violence. In India, even legislations addressing domestic violence include the husband and his relatives as possible perpetrators of domestic violence. For instance Section 498 A of the Indian Penal Code made cruelty to the wife by husband or his relatives as a cognizable, non-bailable offense. Similarly, laws that prohibit dowry also consider the act of demanding dowry as a crime that may be committed by the husband and/or his relatives.

\footnotetext{
${ }^{5}$ Although mothers-in-law and sisters-in-law may be involved in the legal proceedings, when we mention "woman," we mean the wife on whom violence has been inflicted.
} 
We coded the judgments to analyze whether the husband, father-in-law or mother-in-law was implicated, convicted, or acquitted. Out of 164 cases, the husband was convicted in 68 cases while he was implicated of the crime in more than 147 cases. Mothers-in-law were convicted in 23 cases while they were implicated of the crime in 100 cases. Thus, the husband was implicated in $90 \%$ of the cases and the mother-in-law was implicated in $61 \%$ of the cases. In many cases, several members of the family were implicated simultaneously. The trend in the conviction pattern points to the court recognizing the involvement of the extended family in cases of domestic violence which is as articulated in the laws. Refer to table 3.

Table 3

\section{Charges and Convictions}

\begin{tabular}{|l|l|l|}
\hline Family Member/s & Implicated & Convicted \\
\hline $\begin{array}{l}\text { Mother-in-law \& Husband \& Father-in- } \\
\text { law }\end{array}$ & $68(42 \%)$ & $7(4.3 \%)$ \\
$\begin{array}{l}\text { Mother-in-law \& Husband } \\
\text { Mother-in-law \& Father-in-law }\end{array}$ & $21(13 \%)$ & $7(4.3 \%)$ \\
$\begin{array}{l}\text { Mother-in-law alone } \\
\text { Mother-in-law, Husband, Father-in-law } \\
\text { and Others }\end{array}$ & $4(2 \%)$ & $5(3 \%)$ \\
$\begin{array}{l}\text { Total - cases mother-in-law was } \\
\text { implicated }\end{array}$ & $2(1.2 \%)$ & $4(2.4 \%)$ \\
& $\mathbf{1 0 0 ( 6 1 \% )}$ & $\mathbf{2 3 ( 1 4 \% )}$ \\
$\begin{array}{l}\text { Husband alone } \\
\text { Husband \& Father-in-law }\end{array}$ & $51(32 \%)$ & $49(30 \%)$ \\
$\begin{array}{l}\text { Father-in-law alone } \\
\text { Not Clear/Not Applicable } \\
\text { Total - cases mother-in-law was not } \\
\text { implicated or charge was unclear/was } \\
\text { not convicted }\end{array}$ & $7(4 \%)$ & $5(3 \%)$ \\
& 0 & $1(1 \%)$ \\
$86(52.4 \%) * *$ \\
TOTAL & $\mathbf{6 4}(\mathbf{3 9 \%})$ & $\mathbf{1 4 1 ( 8 6 \% )}$ \\
\hline
\end{tabular}

*In some cases, it was not clear whether other members of the family were included. There were 3 cases where it was not clear if the mother-in-law was implicated along with the husband. There were 2 cases where it was not clear if the father-in-law was implicated along with the husband.

** No one was convicted because of procedural impasse. That is in many cases the accused had died before the judgment and therefore the court does not proclaim a verdict. 
The conviction of the mother-in-law is often accompanied by conviction of the husband and/or the father-in-law. As noted in table 3, the mother-in-law alone was implicated in $5(3 \%)$ of the cases while she is implicated with the husband and father-in-law in 68 (42\%) of the cases. The mother-in-law was implicated alone or with other members of the family in 100 (61\%) of the cases but was convicted in $23(14 \%)$ of cases. In contrast, the husband alone was charged in $51(32 \%)$ of the cases and convicted in $49(30 \%)$ cases. The husband was therefore charged and implicated in more number of cases than the mother-in-law. Although it is clear that the associations of the mother-in-law with men in the family are a key aspect of domestic violence in India, the court rulings are less likely to implicate and charge the mother-in-law. We elaborate on the quality of these associations in our discussion of the two main themes in the next section.

Although the law includes the husband and his relatives as potential perpetrators of violence, we find that husbands are most likely to be implicated and convicted of the crime, especially when the victim (the woman) had died. The collective nature of the domestic violence crimes results in contrasting judgments regarding conviction or acquittal of the husband. In fact, in some cases, the husband, by virtue of his closeness to the victim was expected to explain the sequence of events which led to the death of the victim. There were cases where the husband was convicted if he was unable to explain the unnatural death of the victim. For instance, in the case of State of West Bengal versus Dipak Halder (2009), the decision says:

No reason has been assigned as to why accused Dipak Halder did not explain in his examination under Section 313 Cr.P.C. as to how fire occurred. No reason has been explained as to what led the deceased to come out of the house and seek shelter at the varandah of others. There is not a single evidence that accused Dipak Halder made any attempt to put off the fire of his wife. Even in the examination under Section 313, Cr.P.C. 
he does not say that he tried to put off the fire. On the contrary there is sufficient circumstantial evidence that accused Dipak Halder resisted the deceased from going out of the house to save her life (State of West Bengal versus Dipak Halder 2009).

In this case the burden of proof is placed on the husband to explain the occurrence of the fire that caused the death of the woman. Circumstantial evidence is critical in the case of domestic violence crimes particularly because of the private nature of the crime. However, there were cases where absence of evidence was used to acquit the husband. This is demonstrated in the case of State of Karnataka versus M.V. Manjunathegowda \& Anr (2003) in which the decision says:

...the entire prosecution story with regard to the offence of murder under Section 302 IPC, rests on the circumstantial evidence. It is now well-established principle of law that in the case of circumstantial evidence the chain must unerringly link to the guilt of the accused. There is no evidence on record to show that there was a trail of blood from the house to the place where the dead body was found in the well. There was no evidence of dragging the body. The recovery of blood stained shirt and lungi and MO 11 (axe), said to have been stained with blood, seized at the instance of the accused was disbelieved by the High Court. We are also of the view that dragging of body of the deceased from the house to the well, where the dead body was found, could not be the handy work of an individual. The accused must have been assisted by the other inmates of the house in as much as there were seven inmates in the house on the fateful day. The High Court on reappreciation of the evidence, with regard to the offence under Section 302 IPC, came to the conclusion that the prosecution had failed to establish complete and conclusive chain of circumstances to bring the guilt of A-1 beyond reasonable doubt. 
In this case the court was convinced that a homicide had occurred. Yet the husband was acquitted of the crime because the court believed that the murder could not have been the "handy work of an individual" and the state could not provide adequate evidence to suggest that the husband was responsible. This points to the ambiguity with which the Indian legal system approaches domestic violence. While the law recognizes that domestic violence can be a collective crime, the criminal justice system is designed to adjudicate on the individual's role in the criminal action. Due to the private nature of the crime, accounting for individual culpability in a collective crime is sometimes a challenge. However as shown above, in most cases the husband is ascribed the largest responsibility for the crime by virtue of his relationship with the victim.

Of all the laws discussed here, section 498A has seen support and opposition particularly because the offence is non-bailable. A spate of reports about the misuse of the section by means of false/exaggerated allegations and implication of several relatives of the husband were received by the courts. Keeping in view the representations received from various quarters and observations made by the Supreme Court and the High Courts, India's Home Secretary through his letter in 2009, requested the Law Commission of India to consider suggesting amendments, if any, to Section 498A or other measures to check the alleged misuse of the said provision. The conviction rate in respect of the cases under $498 \mathrm{~A}$ is quite low - it is about $20 \%$ - and this includes cases in courts at the state and national level (Government of India 2012).

Interestingly, there is no reliable data to reveal the extent of abuse or misuse (Government of India 2012). However, it is possible that the judgments which are merely appeals for quashing a case at a lower court may pertain to section 498A. Quashing a case in the lower court suggests that from the available evidence, the Supreme Court did not see the case 
worthy of indictment. A total of 26 cases (about 16\%) pertain to quashing cases as not being in the jurisdiction of the lower court which is a little lower than the $20 \%$ reported by the Law Commission for all cases across courts - lower courts state High Courts, and national level Supreme Court.

The most recent (2012) report about Section 498A by India's Law Commission notes that "... the point to be noted is that the value to be attached to the rights of women are no less than the value to be attached to the family as a unit and vice-versa. The challenge before the community is to ensure the promotion of both values. The emphasis should therefore be on wise moderations without overlooking the need and relevance of the retention of penal sanctions necessary to protect and promote women's rights and interests" (p. 15). However, the safeguard against arbitrary and unwarranted arrests lies in strictly observing the letter and spirit of the conditions laid down in the law as relating to power of arrest and sensitizing the police on the modalities to be observed in cases of this nature. The purported misuse of 498A also provides some insights into the inadequacy of the criminal law in dealing with various types of violence ranging from verbal abuse to even murder. The criminalization of verbal abuse by extended family members is often interpreted as misuse of 498A. However it may be useful to examine the content of the judgments. We turn now to the discussion of the two predominant themes in our qualitative analysis.

\section{Thematic Analysis}

Our analysis of the textual data yielded two main themes. The first theme examines the gendered nature of familial relations beyond the intimate partner relationship that comes to bear on domestic violence against the wife. The second theme we discuss is the cultural pervasiveness 
of the gendered relationships from the natal home to the marital family making victims of domestic violence isolated and 'homeless'.

\section{Family Relationships and Violence}

The Supreme Court's rulings clearly note that domestic violence in the Indian context is somewhat of a collective crime occurring within the extended family or the joint family. In 107 of the 164 cases we analyzed, the victim lived in a joint family. In this section, we examine the social relations of power within the family; not merely that between intimate partners. As described above, age and gender play an important role in how power relations are organized in the Indian family. Young brides who live with their extended family are expected to be submissive and obedient to men and to older women in the family. Thus, a 'good' bride is expected to conform to gender norms. A newly arrived daughter-in-law is expected to be adept in all household chores but the situation changes as women grow older.

Women gain formal and informal power in the family through their position as the mother of a son or as the wife of the man who is the oldest son (in term of birth order). As discussed above, dowry is negotiated at the time of marriage but demands may continue later in marriage as well. Husbands and their family members often demand dowry as an entitlement. This notion of entitlement is embedded in the gendered structure of the family in that men are privileged and women's families are therefore expected to meet the demands of the groom and his family. In order to maintain this gendered structure, women from the husband's family, specifically the mother-in-law, may perpetrate violence against the daughter-in-law. Consider the case of Satya Narayan Tiwari versus State of Uttar Pradesh (2010) in which Satya Narayan's wife was brutally murdered by her husband and mother-in-law for dowry. In this case, a car was being demanded from the bride's family. 
There is the testimony of demand of Maruti Car [Maruti is the brand name] being pressed by the two accused persons after about six months of the marriage of the deceased (which took place about three years before the incident) and of her being pestered, nagged, tortured and maltreated on non-fulfillment of the said demand which was conveyed by her to her parents from time to time on her visits to her parental home and on telephone... Seemingly, violence had first been applied to her inside the bedroom by the accused and offering resistance she had somehow run out to the Chajja [balcony] adjoining the room and the blood dropped there...To incapacitate her of any meaningful resistance, the accused persons interfered with her breathing process with the compression of the windpipe of her neck before burning her. Strangulating her half way to overpower her and to render her incapable of offering any meaningful resistance, the two accused then poured kerosene over her and burnt her. (Satya Narayan Tiwari versus State of Uttar Pradesh 2010)

In this case the mother-in-law and her son engaged in violence against the young wife or the bride, when her natal family (the wife's) was unable to meet the demand for a car. This case ruling by the court demonstrates how the mother-in-law exerts power through her son. In the case of Satya Narayan Tiwari versus State of Uttar Pradesh 2010, the father of the bride had met with her father-in-law to seek his assurance of his daughter's safety. The father-in-law named Ghanshyam had assured the father of the bride that his daughter would be safe. However, later in the judgment the Supreme Court decision states:

It appears that Ghanshyam could not control the disposition of his wife and son (the two accused) and they continued to pursue their greed by tormenting and maltreating the 
young lady (deceased) to get a Maruti Car in dowry from her parents. (Satya Narayan Tiwari versus State of Uttar Pradesh 2010)

Thus, both the father of the bride as well as the court assume that the father-in-law is in a position to "control" the actions of his wife (husband's mother), the mother-in-law of the victim. Such assumptions suggest that the mothers-in-law may achieve power in the family, but still as perceived by the court, may occupy positions that are secondary to the men in the family.

In another case of Rajendran versus State Assistant Commissioner (2008), the husband, mother-in-law and the father-in-law engaged in violence against the bride because she gave birth to a girl child. Moreover, because there was a death in the family after the birth of the girl child, the family members believed that the birth of the girl child had brought bad luck to the family. As a result, the other family members, including the mother-in-law began to torture the young woman. The daughter-in-law of the family is considered to be the carrier of good luck and prosperity for the family and her perceived inability to do so, provided the justification for inflicting violence on her. Therefore, protecting the family was a legitimate reason to engage in violence against the young wife.

In both cases, discussed above, the legitimacy for the mother-in-law to engage in violence against the young bride is derived from her position as the mother of the son. If analyzed in isolation, the actions of the mother-in-law do not seem to conform to gender norms. Usually men and women are held accountable to their sex category and therefore are expected to behave accordingly (West and Zimmerman 1987). However, as evident in these cases, some women engage in atypical behavior within the family - a sense of power in complicity with men typically the son - that subordinates women. Thus women are able to reject gender norms when 
it contributes to domination of men and submission of women and consequently enable maintaining gender relations within the family.

\section{Homeless in their own home}

Typically, young brides entering their marital home experience familial gender relations that do not entirely differ from their natal home. Under these circumstances, women victims of domestic violence lack support even from their natal families. When the young wife recognizes that her life is in danger in the marital home, she often seeks assistance from her own parents and/or siblings but she seldom receives support. In most discussions of domestic violence, the focus is on the husband and his family.

In the analysis that follows, we draw attention to the prevalence of the structure of gendered relations not only in the marital families but also in the natal families of young women. The focus on the natal family is important in the study of domestic violence in India because women often turn to their birth families, rather than law-enforcement institutions, for support. We argue that gender relations are embedded in the natal family as well as the marital home which renders the young woman 'homeless' when she faces violence. By focusing on the natal family we also complicate the notion of the young woman (the wife) as being a 'passive' victim of domestic violence particularly in India. This theme recurred in about $11 \%$ of the cases.

In most of the domestic violence cases reaching the Supreme Court, the young woman had already died (in $68 \%$ of the total cases). The Court views young women in Indian families as passive, helpless victims. This is evident in the case of K. Prema Rao and Anr versus Yadla Srinivasa Rao and others (2002) where the judgment says,

"Frailty thy name is woman," that is how in one of his plays Shakespeare described one of the female characters in his play. This description is more and more in evidence particularly in rural Indian society where married women, who are unable to muster 
courage to fight against cruelty and harassment, meted out to them by their spouses and family members find no escape other than ending their own life (K. Prema Rao and Anr versus Yadla Srinivasa Rao and others 2002).

However our analysis suggests that victims of domestic violence were neither passive nor afraid to fight violence. In most cases, as women faced violence in their marital homes, they usually informed their natal family and sought support. Unfortunately, more often than not, the natal family responded by negotiating with the husband and his relatives. Moreover, parents and other members of the natal family convince the victim to 'adjust' to the environment of her marital family inspite of knowing that her (daughter) life was in danger. This is evident in the case of Deen Dayal versus State of Uttar Pradesh (2009) where the judgment quotes the father of the young wife as follows:

Two months before death of Asha Devi, Deen Dayal father-in-law of Asha Devi had come to our house for taking her. Deen Dayal had demanded chain of gold for his son and rupees ten thousand and he had asked to send Asha Devi. My daughter was not prepared to go. But we made her to comprehend and then she was sent. Deen Dayal took Asha Devi with him in anger.

Later the judge corroborates the above testimony of the young wife's father. Their inability to meet his demand had caused him annoyance and anger. Asha Devi was naturally apprehensive and was very reluctant to go with him. But they somehow prevailed upon her and made her depart with him. There is thus positive evidence of her being subjected to harassment.

As evident in this case, Asha Devi the young wife, is not a passive victim of domestic violence. Rather she had informed her natal family about her experience of violence in her marital 
relationship and even declined to go to her marital home. Even in the face of violence, the victim's family convinced her to join her husband. This case shows that young women's lives, before and after marriage, are entangled in familial gender relations. Similar instances are evident in several of the 164 cases we analyze. For instance, in Jagjit Singh versus State of Punjab (2009) the judgment by the court describes a similar situation:

Jasprit Kaur had also informed her father that the accused had made her life miserable at their house and made living there impossible. The complainant Avtar Singh and his wife consoled Jasprit Kaur and sent her back to the house of the accused by telling her that they will inform her about the demand in a day or two.

In this case too, the parents of the young wife had her return to her marital home even when she informed them of the danger awaiting her. Cases such as that of Asha Devi and Jasprit Kaur show that power or lack of it is transmitted to other members of the family as the gender structure is deeply embedded in the Indian family system. Moreover, the father of the victim has relatively less power in relation to the groom's family and in contrast to the power achieved by the mother-in-law through her son. Rather than question the violence inflicted on his daughter, he tries to meet the demands of the groom's family, however unreasonable it may be. Thus, gender inequality is reinforced through family relations (both marital and natal) leaving the victim isolated when she faces violence.

These cases also bring to the forefront another important issue and that is the victim not approaching law-enforcement agencies in the absence of support from either the natal or the birth family. One plausible reason, as evident from the rulings, is the fear of losing a marital life that is deeply valued in society. An example is the case of Satya Narayan Tiwari versus State of Uttar 
Pradesh (2010). In this case, the natal family chooses to seek a compromise and the victim too does not choose to take legal recourse for fear of losing her marital life. The judgment says:

On her visits to her parental house, she (deceased) used to narrate to him (this witness) her torture and maltreatment. She had also informed him in this behalf on telephone. Both the accused were there at their home at Farrukhabad and repeated the demand of Maruti car. On his expressing inability to meet this demand, he and Jaideo Awasthi were insulted and humiliated and turned out of the house. Both the accused told them not to visit their house again without meeting their demand of a Maruti Car. Surya Kant Dixit PW1 then went to Geeta's father-in-law at the place of his employment- State Bank because he was a gentleman. He apprised him of the conduct of his wife and son (accused) pressing the demand of Maruti Car. He, however, offered consolation. Geeta, daughter of Surya Kant Dixit DW 1, also advised him not to take any action and he went away. The victim might have thought that making of FIR by her father at that juncture would ruin her matrimonial life and so she advised him not to take any legal step at that time (Satya Narayan Tiwari versus State of Uttar Pradesh 2010) [our italics].

In this case, the victim, Geeta, informed her natal family about the violence but did not choose to take legal recourse. The priority accorded to the institution of marriage even in the face of violence is yet another part of the gendered structure of the Indian family structure. Not only do the groom's family feel entitled to make demands of the bride's family, but the bride's family too do not desire to break the relationship even if it means the daughter is facing violence.

\section{Discussion and Conclusion}

In this paper we discuss domestic violence as an intra-family dynamic that extends beyond intimate partner relationships. While the law recognizes that domestic violence can be a 
collective crime, the criminal justice system is designed to adjudicate on the individual's role in the criminal action. The Supreme Court's rulings clearly note that domestic violence in the Indian context is somewhat of a collective crime occurring within the extended family or the joint family. Due to the private nature of the crime, accounting for individual culpability in a collective crime is sometimes a challenge. We call attention to the collective nature of the domestic violence crime in India where mothers-in-law were seldom convicted alone (3\% of cases) but were more likely to be convicted along with other members of the family.

First, this paper demonstrates that in an extended family, women in positions of power engage in violence against other women in the family but this does not lead to an overall change in gender relations within the institution of the family. The judgments analyzed in this paper highlight the power of the mothers-in-law as they engage in violence against the newly married daughters-in-law. Yet, such display of power does not necessarily change gender relations within the family but rather exacerbates it. The mother-in-law, inspite of her power, continues to occupy a secondary position in the family as she derives power through her association with men in the family. It is only by upholding the higher status of the men in the family that she is able to subordinate the young wife.

Second, our analysis demonstrates how atypical gender behavior is accepted when the outcome is the continued maintenance of the gender structure. Gender theory suggests that people are held accountable to their sex category (West and Zimmerman 1987). As perpetrators of violence, mothers-in-law do not conform to gendered behavior but they are not held accountable within their own families for the non-conformance (although they are held accountable by the court). This suggests that non-conformance to gender roles is accepted when it aids maintaining the gender structure within the institution of the family. Transgressing gender 
norms is considered an important act of resistance and therefore one that contributes to social change (Risman 2004; Deutsch 2007). However, our analysis show that transgressions by mothers-in-law enable preserving gender inequality while assisting individual women exert power even if it may be secondary to the men in the family.

Finally, our analysis brings attention to the pervasiveness of the gender structure beyond the intimate partner relationship. Most policies which address domestic violence focus on the intimate partner and the marital family (in the case of Indian law). The role of the natal family in being somewhat complicit in this gendered violence is made invisible most of the time. ${ }^{6}$ From when the unmarried daughter is considered a burden, and until when those in the natal family advise their daughter to 'adjust' to the marital family, the natal family enables the system of violence. However, unlike the marital family, where violence is about power, the natal family's unintended support of violence, is a demonstration of their powerlessness in the larger gender structure. By drawing attention to this 'unintended' violence, we argue that any policy that seeks to address domestic violence has to consider the structure of gender relations in both the marital and natal home. However, punitive action against the natal family cannot be the way forward.

As we saw in some cases discussed above, the unintended support for violence from the natal family is an indication of their powerlessness and therefore further victimization through the law will not help. However, insights from this paper have important policy implications. It is critical that natal families re-frame their powerlessness which is often derived from their status as families with daughters. Considering that most women in India turn to their natal families first

\footnotetext{
${ }^{6} \mathrm{~A}$ daughter is seen as a liability by most parents because she has to be married and she 'belongs' in the marital family.
} 
for support when they face violence in their marriages, policy must enable such families to act and utilize the law. 


\section{References}

Abraham, M. (2005). Fighting back: Abused South Asian women's strategies of resistance. In N. J. Sokoloff \& C. Pratt (Eds.), Domestic violence at the margins: Readings on race, class, gender, and culture (pp. 253-271). New Jersey: Rutgers University Press.

Agnes, F. (1992). Protecting Women against Violence-Review of a Decade of Legislation, 198089. Economic and Political Weekly 27(17), 27(17):WS19-WS21+WS24-WS33.

Agnes, F. (2011). The Concubine and Notions of Constitutional Justice. Economic and Political Weekly, 46(24), 31-33.

Ahuja, R., Bangdiwala, S., Bhambal, S., Jain, D., Jeyaseelan, L., \& Kumar, S. (2000). Domestic violence in India- a summary report of a multi-site household survey. Washington DC: International Center for Research on Women.

Anderson, K. L. (2010). Conflict, power, and violence in families. Journal of Marriage and Family, 72(3), 726-742.

Berg, B. L., \& Lune, H. (2004). Qualitative research methods for the social sciences (Vol. 5). Boston: Pearson.

Breiding, M. J., Basile, K. C., Smith, S. G., Black, M. C., \& Mahendra, R. R. (In press). Intimate partner violence surveillance: Uniform definitions and recommended data elements: Version 2.0: Centers for Disease Control and Prevention, National Center for Injury Prevention and Control Atlanta, GA.

Brown, W. (1995). States of injury: Power and freedom in late modernity. Princeton, NJ: Princeton University Press.

Brush, L. D. (2003). Gender and governance. Walnut Creek, CA: Altamira Press.

Butalia, S. (2002). The Gift of a Daughter: Encounters with Victims of Dowry. Penguin Books India. 
Cherukuri, S., Britton, D. M., \& Subramaniam, M. (2009). Between Life and Death Women in an Indian State Prison. Feminist Criminology, 4(3), 252-274.

Collins, P. H. (1998). It's all in the family: Intersections of gender, race, and nation. Hypatia, 13(3), 62-82.

Connell, R. W. (1987). Gender and power: Society, the person and sexual politics. Stanford, CA: Stanford University Press.

Crenshaw, K. (1991). Mapping the margins: Intersectionality, identity politics, and violence against women of color. Stanford law review, 1241-1299.

Dave, A., \& Solanki, G. (2000). Domestic Violence in India. A Summary Report of Four Research Studies. . Washington DC: International Centre for Research on Women.

Deutsch, F. M. (2007). Undoing gender. Gender \& Society, 21(1), 106-127.

Dobash, R. E., \& Dobash, R. (1979). Violence against wives: A case against patriarchy. New York: Free Press.

Eisenstein, H. (1996). Inside agitators: Australian femocrats and the state. Philadelphia: Temple University Press.

England, P. (1998). What do we Mean When We Say Something is Gendered? In $O$. Organizations, and Work, A section of the American Sociological Association (Ed.), Fall 1998 Newsletter.

Ferguson, J., \& Gupta, A. (2002). Spatializing states: toward an ethnography of neoliberal governmentality. American ethnologist, 29(4), 981-1002.

Fernandez, M. (1997). Domestic violence by extended family members in India: Interplay of gender and generation. Journal of Interpersonal Violence, 12(3), 433-455.

Ferree, M. M. (1990). Beyond Separate Spheres: Feminism and Family Research. Journal of 
Marriage and Family 52(4), 866-884.

Gangoli, G., \& Rew, M. (2011). Mothers-in-law against daughters-in-law: Domestic violence and legal discourses around mother-in-law violence against daughters-in-law in India. Women's Studies International Forum, 34(5), 420-429.

García-Moreno, C., Jansen, H. A., Ellsberg, M., Heise, L., \& Watts, C. (2005). WHO multicountry study on women's health and domestic violence against women: initial results on prevalence, health outcomes and women's responses: World Health Organization.

Ghosh, B., \& Choudhuri, T. (2011). Legal protection against domestic violence in India: scope and limitations. Journal of Family Violence, 26(4), 319-330.

Government of India. 2012. Law Commission of India. Report No, 243 on Section 498A IPC. Accessed at http://lawcommissionofindia.nic.in/reports/report243.pdf on March 24th 2015.

Griffiths, P., Matthews, Z., \& Hinde, A. (2002). Gender, family, and the nutritional status of children in three culturally contrasting states of India. Social Science \& Medicine, 55(5), 775-790.

Gupta, M. D. (1987). Selective discrimination against female children in rural Punjab, India. Population and Development Review, 77-100.

Hoffman, K. L., Demo, D. H., \& Edwards, J. N. (1994). Physical wife abuse in a non-Western society: an integrated theoretical approach. Journal of Marriage and Family, 131-146.

Kandiyoti, D. (1988). Bargaining with patriarchy. Gender \& Society, 2(3), 274-290.

Kapur, R. (2005). Erotic justice: Law and the new politics of postcolonialism. London, UK: Glass House Press.

Kapur, R., \& Cossman, B. (1996). Subversive sites: feminist engagements with law in India. New 
Delhi: Sage Publications.

Karlekar, M. (1998). Domestic Violence. Economic and Political Weekly 33(27), 1741-1751

Katzenstein, M. F. (1989). Organizing against violence: Strategies of the Indian women's movement. Pacific Affairs, 53-71.

Katzenstein, M. F. (1991). Getting Women's Issues onto the Public Agenda: Body Politics in India'. Samya Shakti, 6, 1-16.

Kishwar, M. (1988). Rethinking dowry boycott. Manushi, 48, 10-13.

Krishnan, P., \& Subramaniam, M. Dowry, Domestic Violence and Gender: Legal interpretations by India's Supreme Court. Unpublished paper

Lakshmi.C.S. (1989). “On Kidneys and Dowry.” Economic and Political Weekly, 24(4), 189-90.

Leslie, J. (1998). Dowry, dowry deaths, and violence against women: A Journey of Discovery. In W. Menski(Ed.), South Asians and the Dowry Problem(pp.21-35) . Trentham Books Limited, London, UK.

Loseke, D. R. (2005). Through a Sociological Lens: The Complexities of Family Violence. . In D. R. Loseke, R. J. Gelles, \& M. M. Cavanaugh (Eds.), Current Controversies on Family Violence (pp. 35-48). Thousand Oaks, CA: Sage Publications.

Madan, T. N. (1993). The kinship map of India. In P. Uberoi (Ed.), Family, kinship and marriage in India (pp. 416-434). New Delhi, India: Oxford University Press.

Martin, P. Y. (2003). "Said and Done” Versus "Saying and Doing” Gendering Practices, Practicing Gender at Work. Gender \& Society, 17(3), 342-366.

Mazur, A. (2001). State Feminism Women's Movements and Job Training: Making Democracies Work in the Global Economy. New York: Routledge.

Mehra, M. (1998). Exploring the boundaries of law, gender and social reform. Feminist Legal 
Studies, 6(1), 59-83.

Menon, N. (1998). State Gender Community-Citizenship in Contemporary India. Economic and Political Weekly, 33(5), PE3-PE10.

Menon, N. (2004). Recovering subversion: Feminist politics beyond the law. Illinois: University of Illinois Press.

Messer, E. (1997). Intra-household allocation of food and health care: current findings and understandings—introduction. Social Science \& Medicine, 44(11), 1675-1684.

Narayan, U. (2013). Dislocating cultures: Identities, traditions, and Third World feminism. New York: Routledge.

National Crime Records Bureau. (2013). Crime in India 2013. Ministry of Home Affairs. http://ncrb.gov.in/CD-CII2013/home.asp accessed on May 3, 2015

Netting, N. S. (2010). Marital ideoscapes in 21st-century India: Creative combinations of love and responsibility. Journal of Family Issues, 31(6), 707-726.

Ortiz-Barreda, G., \& Vives-Cases, C. (2013). Legislation on violence against women: overview of key components. Revista Panamericana de Salud Pública, 33(1), 61-72.

Palriwala, R. (2009). “The Spider's Web: Seeing dowry, fighting dowry.” In T.Bradley, E. Tomalin and M. Subramaniam (Eds.) Dowry: Bridging the Gap between Theory and Practice (pp1-28). New Delhi, India: Women Unlimited.

Panchanadeswaran, S., \& Koverola, C. (2005). The voices of battered women in India. Violence against Women, 11(6), 736-758.

Risman, B. J. (2004). Gender as a Social Structure Theory Wrestling with Activism. Gender \& Society, 18(4), 429-450.

Sen, A. (1993). The economics of life and death. Scientific American, 268, 40-40. 
Stetson, D. M. (2001). Abortion Politics, Women's Movements, and the Democratic State: A Comparative Study of State Feminism: A Comparative Study of State Feminism. Oxford: Oxford University Press.

Subramaniam, M., Remedios, K., Mitra, D. (2009). Dowry and Transnational Activism. In T. Bradley, E. Tomalin, \& M. Subramaniam (Eds.), Dowry: bridging the gap between theory and practice (pp. 197-225). London, UK; New Delhi, India: Zed, Women Unlimited.

Subramaniam, M., Krishnan, P., \& Bunka, C. (2014). Women's Movement Groups in State Policy Formulation: Addressing Violence against Women. Indian Anthropologist, 44(1), $37-52$.

Sunder Rajan, R. (2003). The scandal of the state: Women, law, and citizenship in postcolonial India. Durham, NC: Duke University Press.

Suneetha, A., \& Nagaraj, V. (2005). Adjudicating (Un)Domestic Battles. Economic and Political Weekly, 40(38), 4101-4103.

Visaria, L. (2000). Violence against Women. Economic and Political Weekly, 35(20), 17421751.

West, C., \& Zimmerman, D. H. (1987). Doing gender. Gender \& Society, 1(2), 125-151.

Yllö, K. A. (2005). “Through a Feminist Lens: Gender, Diversity, and Violence: Extending the Feminist Framework.” In D. Loseke, R. J. Gelles, \& M. Cavanaugh (Eds.), Current controversies on family violence (pp. 19-34). Thousand Oaks, CA: Sage Publications. 